\title{
What happens to your social media account when you die? The first German judgments on digital legacy
}

\author{
Angelika Fuchs 1
}

Accepted: 4 February 2021 / Published online: 10 February 2021

(C) @ ERA 2021

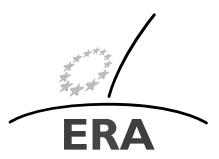

EUROPÄISCHE RECHTSAKADEMIE

ACADEMY OF EUROPEAN LAW ACADEMIE DE DROIT EUROPEEN ACCADEMIA DI DIRITTO EUROPEO TRIER - TREVES - TREVIRI

The digital estate is becoming a major focus of discussions on both national and international inheritance law. It has also become a popular topic at the ERA Annual Conference on European Succession $\mathrm{Law}^{1}$ and advisory practice will have to increasingly take it into account.

Recently, the first German judgments have been delivered: they focus on the question of whether an account on a social network with all its communication content can pass to the user's heirs by way of universal succession and moreover if and how access to the account has to be granted. These issues at stake have been at the centre of a legal dispute lasting several years between the parents of a fifteen-year-old girl who was the victim of a fatal incident in 2012 and Facebook.

This article follows the chronology of the judgments delivered by the Berlin Regional Court, the Court of Appeal and the Federal Supreme Court - in a first and in a second round - with the final decision of the Federal Supreme Court eventually issued in late summer 2020.

\section{Facts}

On the evening of 3 December 2012, a fifteen-year-old girl was fatally struck, under as yet unexplained circumstances, by an underground train entering a station. The

\footnotetext{
${ }^{1}$ A workshop on digital inheritance organised by Dr Stephanie Herzog and Professor Francesco Paolo Patti took place at the most recent Annual Conference on Succession Law, held on 5-6 November 2020.
}

A. Fuchs

afuchs@era.int

1 Head of Section European Private Law, ERA, Trier, Germany 
driver of the underground train demanded that the parents, as heirs, pay compensation for his pain and suffering as well as compensation for loss of earnings, as suicide was to be assumed.

The parents hoped that her daughter's Facebook account would provide them with information about her daughter's possible intentions or motives in the event that her death was a suicide. The mother tried to log into the user account using her daughter's access data. However, she was unsuccessful because the account had already been set to the so-called memorial state shortly after the accident. According to Facebook, the activation of the memorial state was initiated by a user whose name could not be mentioned for reasons of data protection. Facebook friends of the deceased could access the memorial and add posts there but could not see the user account (to which only Facebook still had access).

The mother explained that her daughter had given her the password and had allowed her to access her data. She asked Facebook to unblock the user account but Facebook refused, citing the terms of use and pointing out that it did not hand out the profile data of deceased users as a matter of principle.

\section{First round}

\subsection{Berlin Regional Court (2015)}

In a judgment of 17 December $2015,^{2}$ the Berlin Regional Court ruled that the mother was entitled to access her daughter's Facebook account, arguing that the contract for the use of Facebook services, which the daughter had entered into, was transferred to the heirs like any other contract. This is to say that the digital and the "analogue" assets of the deceased would be treated alike in the event of death. A personal diary for instance would be inherited regardless of its content and the same should be the case for emails and private Facebook messages. This implied that Facebook could not rely on data protection law: confidential letters sent by a third party could be read by the heirs after the death of their recipient and the same applied to digital messages.

Furthermore, the Court argued that the parents were responsible for protecting the rights of their underage daughter, a responsibility which did not merely apply during her lifetime. In any event, if special circumstances - such as the unexplained cause of death of the daughter - existed, the parents were entitled as heirs to obtain knowledge of what their daughter had said on the internet.

The memorial state directive used by Facebook meaning that any person could bring the user's profile to a state of remembrance was invalid as it caused an unreasonable disadvantage to the heirs. As a result, the Berlin Regional Court ordered Facebook to give the parents access to the Facebook account of the underage daughter.

${ }^{2}$ LG Berlin, 20 O 172/15, ECLI:DE:LGBE:2015:1217.200172.15.0A. 


\subsection{Berlin Court of Appeal (2017)}

On appeal by the defendant, the Court of Appeal reversed the first instance judgment and dismissed the action. ${ }^{3}$ According to the Berlin Court of Appeal, the parents had no right to access the Facebook account and the communication content stored in it after the death of the child. The contract concluded between the daughter and Facebook, like other contracts, was transferred to the heirs upon the death of the account holder, but Facebook was prevented from disclosing to the parents the contents of their daughter's communications due to the secrecy of telecommunications.

This decision was met with criticism in the literature, especially because Facebook, by stipulating secrecy obligations in its general terms and conditions, was elevating itself to a guardian of telecommunications secrecy: however, Facebook did not have such a role, because even the post office - which must grant an heir access to a mailbox - is not permitted to sift through the content beforehand, sort it out, destroy it or put it in a "memorial state". 4

\subsection{Federal Supreme Court (2018)}

On appeal by the plaintiff, the Federal Supreme Court (Bundesgerichtshof) set aside the judgment of the Court of Appeal and restored the first instance judgment. ${ }^{5}$ According to the judgment, Facebook's rules on the memorial state had not become part of the contract as they were accessible only on Facebook's webpage.

The Court underlined that the contract of use between the plaintiff's daughter and Facebook was transferred to the heirs by way of universal succession. Its inheritability was not excluded by contractual provisions. Nor did the nature of the contract imply that the contractual relationship was not inheritable. It was not the contract with Facebook which is of a highly personal nature, but rather the content of the account. However, personal belongings are also transferred to heirs: documents such as diaries and personal letters are inherited, and there is no reason to treat digital content differently. A differentiation according to whether digital content was stored on a local storage medium such as a hard disk or a USB stick (and thus passed to the heir without further ado) or was located on the servers of a service provider would be incoherent.

The Court furthermore denied any exclusion of inheritability on the basis of the testator's post-mortem personal rights ${ }^{6}$ and the personality rights of her Facebook friends. The user of a social network knew just as little as the writer of a letter who would ultimately take note of the content of the message. The sender might trust that his or her message would only be made available to the selected recipient account, but he or she had to expect that third parties could potentially gain knowledge of the content of the message - both during the lifetime of the account holder and in the event of death.

\footnotetext{
${ }^{3}$ Kammergericht, Judgment of 31 May 2017 - 21 U 9/16, ECLI:DE:KG:2017:0531.21U9.16.0A.

${ }^{4}$ Gloser [1], p. 310. Cf. Herzog [2] p. 3750: The synchronisation of the online and offline world is indispensable ("unabdingbar").

${ }^{5}$ BGH, Judgment of 12 July 2018 - III ZR 183/17, ECLI:DE:BGH:2018:120718UIIIZR183.17.0.

${ }^{6}$ The matter was considered differently by Hoeren [4], p. 749.
} 
Nor did the secrecy of telecommunications or data protection law conflict with the plaintiff's claim. ${ }^{7}$ The relevant German provision on the secrecy of telecommunication $^{8}$ applied only to individuals or institutions who were not involved in the protected communication process but since the heir was completely in the position of the testator, he or she was not "another" within the meaning of this Article. Applying the EU General Data Protection Regulation, ${ }^{9}$ data protection concerns of the testator were not affected as the Regulation only protected living individuals. ${ }^{10}$ According to the Court, the processing of the personal data of the testator's communication partners and the provision of messages was permissible under Article 6(1)(b) para. 1 GDPR as it was necessary to fulfil the contractual obligations towards the testator's communication partner (irrespective of the death of the account holder). Moreover, it was necessary to fulfil the legitimate overriding interests of the heirs (Article 6(1)(f) GDPR).

\section{Second round}

The landmark ruling of the Federal Supreme Court was unambiguous, clearly structured and thoroughly reasoned. The user contract with Facebook was part of the estate and would therefore pass to the heirs. Facebook was obliged to grant access to the daughter's account.

Unfortunately, however, this judgment was not the last ruling in a long-lasting process which was particularly stressful for the girl's parents. Six weeks after the Supreme Court ruling, Facebook sent the mother a USB stick containing exactly one file - a pdf file of more than 14,000 pages - which, according to Facebook, contained a copy of the data read from the account held by the deceased. The mother claimed that the document was hardly readable, unstructured, partly in English and that it was difficult to search within the text. She sued Facebook seeking the imposition of a penalty payment for failure to comply with the obligation to access the account. The case went again through all instances.

\subsection{Berlin Regional Court (2019)}

The ruling of the Berlin Regional Court was clear: ${ }^{11}$ handing over a USB stick with the content of the account could not be regarded as granting access to the account. "Granting access" meant that Facebook enabled the mother to take note of the contents of the user account in the same way as her daughter had done before. Delivering the contents of the account in a huge pdf file did not fulfil the obligation laid down in the earlier judgment.

\footnotetext{
${ }^{7}$ Cf. Preuß [7], p. 3147; Seifert [9], p. 1177.

${ }^{8} \S 88$ III Telekommunikationsgesetz.

${ }^{9}$ OJ L 119, 4 May 2016; cor. OJ L 127/2, 23 May 2018.

${ }^{10}$ Recital 27: This Regulation does not apply to the personal data of deceased persons. Member States may provide for rules regarding the processing of personal data of deceased persons.

${ }^{11}$ LG Berlin, Order of 13 February 2019 - 20 O 172/15, ECLI:DE:LGBE:2019:0213..200172.15.00.
} 
Insofar as Facebook countered that it could not grant login access to the account whereby only contents were checked but no functions of the service (e.g., the posting of messages) were used, the Berlin Regional Court remained unimpressed. On the one hand, Facebook could create the technical possibilities for the account not to be used actively (read-only or passive mode), because this was solely a question of programming; on the other hand, the mother had neither requested nor intended use of the account. In any case, the mother had to be granted access to the user account for a reasonable period of time.

\subsection{Berlin Court of Appeal (2019)}

Once again, the Court of Appeal ${ }^{12}$ was at odds: the court quoted from the ruling of the Federal Supreme Court and deduced from it that Facebook was obliged only to provide the existing account content. It argued that there was no entitlement to grant access to the account as such and that Facebook was free to decide how to provide the content of the account. The transmission of a USB stick with the communication content of the account was considered to be completely sufficient. It did not matter that the 14,000-page document was not structured and did not contain any navigation aids. In comments on this judgment, Facebook's behaviour of delivering a pdf of 14,000 pages was however classified as obviously brazen. ${ }^{13}$

\subsection{Federal Supreme Court (2020)}

Once more, it was the Federal Supreme Court's turn. ${ }^{14}$ The Court explained its earlier judgment, highlighting that the creditor not only had to be granted access to the communication content held in the user account, but also had to be given the opportunity to take cognisance of the user account itself and the content in the same way as the original authorised person holding the account was able to. The main argument in this reasoning was that the contract of use with its rights and obligations was transferred to the heirs by way of universal succession. Therefore, the heirs were to be granted access to the user account in the same way as their daughter had previously been granted access. By providing a USB stick with an extensive PDF file, this obligation was not fulfilled.

To summarise, it was important that the mother could "go into" the account and not just receive the contents in barely legible form. To put matters differently: it was not sufficient to grant access to the communication content. Access to the account must also be granted.

\footnotetext{
${ }^{12}$ Kammergericht, Order of 9 December 2019 - 21 W 11/19.

${ }^{13}$ Hoeren [5], p. 185.

${ }^{14}$ BGH, Order of 27 August 2020 - III ZB 30/20, ECLI:DE:BGH:2020:270820BIIIZB30.20.0.
} 


\section{Open issues}

This final decision was received with favour in German literature. ${ }^{15}$ In the meantime, Facebook itself reacted and adapted its terms and conditions. ${ }^{16}$

However, even after this landmark ruling, a number of questions remained unanswered. First of all, the facts of this case concerned the death of a minor. The custodial parents were also the sole heirs of the account holder. Whether the decision of the Federal Supreme Court also applied to the same extent to an account holder who had reached the age of majority had not yet been clarified. It should be noted that the contract to open an account on a social network is classified as a contract under the law of obligations and therefore - unlike membership in an association, for example, which is not hereditary - passed to the heir. This, of course, raised the question of whether the inheritability of the account could be excluded in the company's general terms and conditions. Facebook does offer this possibility in its terms and conditions. ${ }^{17}$ It is still an open issue whether it is sufficient for the person concerned to briefly click on the "non-inheritable" button in order to prevent the passing on of his or her access data.

It was proposed in the German Bundestag to draft a law on "regulating access to digital heritage and harmonising it in the EU". ${ }^{18}$ It was suggested, among other things, to introduce a digital certificate of succession and demanded that a clause in general terms and conditions which provides for the non-inheritability of the account should be invalid. The German Ministry of Justice did not see a need for legal action in revising the General Terms and Conditions Act after having presented a huge study of the Fraunhofer Institute. ${ }^{19}$

Ultimately, the big question in this context is who owns the data. If the account is assumed to not be inheritable - be it in principle, be it on the basis of a contractual clause - and access is denied to the heirs (or relatives), the inevitable consequence will be that the data belongs solely to the respective provider (e.g. Facebook). This would once again strengthen the power of the internet giants vis-à-vis the individual consumer.

However, following the landmark rulings of the Federal Supreme Court, there are many good reasons in favour of the inheritability of digital data, at least from a German perspective. This should encourage legal practitioners dealing with inheritance cases to advise their clients to include regulations on the inheritance of their digital

\footnotetext{
${ }^{15}$ Methmann [6], p. 692; Seidler [8], p. 142.

16 "You may designate a person (called a legacy contact) to manage your account if it is memorialized. Only your legacy contact or a person who you have identified in a valid will or similar document expressing clear consent to disclose your content upon death or incapacity will be able to seek disclosure from your account after it is memorialized." (https://www.facebook.com/terms.php, last visited on 8 January 2021).

17 "Deleting your account when you pass away: You can choose to have your account permanently deleted should you pass away. This means that when someone lets us know that you've passed away, all of your messages, photos, posts, comments, reactions and info will be immediately and permanently removed from Facebook." (https://www.facebook.com/help/991335594313139?ref=tos, last visited on 8 January 2021). ${ }^{18}$ http://dipbt.bundestag.de/dip21/btd/19/140/1914044.pdf.

${ }^{19}$ Methmann [6], p. 693; https://www.sit.fraunhofer.de/fileadmin/dokumente/studien_und_technical_ reports/DigitalerNachlass-Studie-Webversion.pdf?_=1594381988.
} 
estate in testamentary dispositions. For those who want to make their own provisions, consumer centres offer valuable help. ${ }^{20}$

Publisher's Note Springer Nature remains neutral with regard to jurisdictional claims in published maps and institutional affiliations.

\section{References}

1. Gloser, St.: Anmerkung zu KG, Urteil vom 31.5.2017. DNotZ 286 (2018)

2. Herzog, St.: Der digitale Nachlass - ein bisher kaum gesehenes und häufig missverstandenes Problem. NJW 3745 (2013)

3. Herzog, St., Pruns, M.: Der digitale Nachlass in der Vorsorge- und Erbrechtspraxis (2018)

4. Hoeren, Th.: Anmerkung zu BGH, Urteil vom 12.7.2018. MMR 740 (2018)

5. Hoeren, Th.: Anmerkung zu KG, Beschluss vom 9.12.2019. MMR 183 (2020)

6. Methmann, F.: Anmerkung zu BGH, Beschluss vom 27.8.2020. MMR 688 (2020)

7. Preuß, N.: Digitaler Nachlass - Vererbbarkeit eines Kontos bei einem sozialen Netzwerk. NJW 3146 (2018)

8. Seidler, K.: Der digitale Nachlass - ein Zwischenstand. NZFam 141 (2020)

9. Seifert, A.: Das digitale Erbe im Spannungsfeld von Persönlichkeitsrechten, Fernmeldegeheimnis und Datenschutz in Deutschland. EuRPrivL 1171 (2019)

${ }^{20}$ https://www.verbraucherzentrale.de/wissen/digitale-welt/datenschutz/digitale-vorsorge-digitalernachlass-was-passiert-mit-meinen-daten-12002 and cf. Herzog/Pruns [3] p. 143 et seq. with practical hints. 